Western University

Scholarship@Western

Aboriginal Policy Research Consortium International (APRCi)

$1-3-2012$

\title{
Justice, culture and the political determinants of indigenous Australian health
}

Dominic O'Sullivan

Follow this and additional works at: https://ir.lib.uwo.ca/aprci

Part of the Other Political Science Commons, and the Sociology of Culture Commons

Citation of this paper:

O'Sullivan, Dominic, "Justice, culture and the political determinants of indigenous Australian health" (2012). Aboriginal Policy Research Consortium International (APRCi). 374.

https://ir.lib.uwo.ca/aprci/374 
Justice, culture and the political determinants of indigenous Australian health

Dominic O'Sullivan

Ethnicities published online 3 January 2012

DOI: $10.1177 / 1468796811432697$

The online version of this article can be found at:

http://etn.sagepub.com/content/early/2012/01/03/1468796811432697

\author{
Published by: \\ @SAGE \\ http://www.sagepublications.com
}

Additional services and information for Ethnicities can be found at:

Email Alerts: http://etn.sagepub.com/cgi/alerts

Subscriptions: http://etn.sagepub.com/subscriptions

Reprints: http://www.sagepub.com/journalsReprints.nav

Permissions: http://www.sagepub.com/journalsPermissions.nav

>> OnlineFirst Version of Record - Jan 3, 2012

What is This? 


\title{
Justice, culture and the political determinants of indigenous Australian health
}

\section{Dominic O’Sullivan}

Charles Sturt University, Australia

\begin{abstract}
Indigenous Australian health is distinguished by a median age of death in the order of 20 years less than that of the non-indigenous population (Australian Bureau of Statistics, 2009). This makes Australia unique among comparable post-colonial societies in failing to make substantive reductions to the indigenous/non-indigenous health differential. Relatively poor indigenous housing, educational attainment, labour market participation and access to traditional resources for economic purposes contribute to the differential. These contributing variables have an inherently political character which is integral to examining the just distribution of public authority, the purpose of political activity, equal political participation and cultural responsiveness in the provision of health services as important theoretical considerations in reducing cross-cultural inequities in the burden of disease.
\end{abstract}

\section{Keywords}

political determinants of health, indigenous Australian health, indigeneity

\section{Introduction}

Constraints on indigenous Australian's capacity for good health raise questions about public decisions in housing, education, economic, environmental and labour market policy which influence indigenous people's access to the good life (Aristotle, 1988) and propensity to enjoy good health. However, the description of these variables as purely social determinants can misleadingly overshadow their inherently political character. Politics is part of the complex social system, and sustained

\section{Corresponding author:}

Dominic O'Sullivan, School of Humanities and Social Sciences, Charles Sturt University, Panorama Avenue, Bathurst, NSW 2795, Australia

Email: dosullivan@csu.edu.au 
policy failure across the wider determinants of health points to the explanatory potential of political and administrative decisions, and the Northern Territory auditor-general's recent partial attribution of poor indigenous housing to these variables (Auditor-General for the Northern Territory, 2010) is illustrative.

Indigenous health is distinguished by a median age of death in the order of 20 years less than that of the non-indigenous population (Australian Bureau of Statistics, 2009), and Australia is unique among comparable post-colonial societies in failing to make substantive reductions to the indigenous/non-indigenous health differential (Oxfam Australia, 2007). This is principally explained by the high incidence of premature but preventable indigenous deaths (Australian Bureau of Statistics, 2009). Between 2001 and 2005, cardiovascular conditions were the most common explanation for the death rates of both men and women, and were higher than the expected 'age cause-specific' rates for non-indigenous people $(3 \%$ and $2.7 \%$, respectively). For men, injuries ( $2.9 \%$ higher), cancers $(1.5 \%)$, respiratory diseases $(4.3 \%)$, and nutritional and metabolic diseases $(7.5 \%)$ were the next most common causes of death (Australian Bureau of Statistics, 2009). For women, cancers (1.6\%), nutritional and metabolic (10.1\%) diseases, and respiratory diseases (3.6\%) (Australian Bureau of Statistics, 2009) most commonly account for the differential.

Equal opportunity for good health is a mark of equal moral worth, just as comparable access to the highest achievable level of health care distinguishes equal citizenship and protects access to political, economic and social liberties. As a matter of distributive justice, public administration should, then, allow each person the same political space to engage with others as their peers, with the same political 'voice' to demand that public institutions provide cultural respect and group recognition as pre-conditions for individual social equity. A consequent rationale for public health policy is that:

... by keeping people close to normal functioning, healthcare preserves for people the ability to participate in the political, social, and economic life of their society. It sustains them as fully participating citizens - normal collaborators and competitors - in all spheres of social life. .

Daniels (2001: 3)

The continued prevalence of trachoma among some indigenous communities is an illustration of public policy failing to provide equitable access to good health. Treating the disease that has been eliminated from every first-world jurisdiction but Australia is a pressing clinical imperative, but it is also a political concern inviting a theoretical account of what indigenous people might fairly expect from the public health system. Therefore, 'theories of justice are necessary to define duties and obligations of institutions and actors in reducing inequalities' (Ruger, 2006a: 998). These ought to be guided by 'a theory of health-care needs [that] must come to grips with two widely held judgements: that there is something especially important about health care and that some kinds of health care are more important 
than others' (Daniels, 1981: 147). In the present context, those aspects of health care that command a reparative as well as a distributive justification assume particular moral urgency. For example, mental health may not be more worthy of public funding, in its own right, than treating sporting injuries acquired through bad luck, but the fact that the prevalence of mental ill health is significant among indigenous people precisely because of the considered policy positions of governments means that it has a unique moral relevance and a particular call on public resources. One perspective from the discipline of psychiatry holds that 'Aboriginal mental health cannot be separated from its historical context' as 'the intergenerational transmission of trauma... socio-cultural dislocation... [and] high rates of grief and loss' (Rege, 2009: 98) continue to account for disproportionate distributions of the burden of disease. The relationship between ill health and access to education and the labour market (Daniels, 1981) compounds colonialism's negative legacy, which is also highlighted by the relative absence of physical conditions such as obesity, diabetes, hypertension and renal or cardiovascular diseases in pre-colonial society (Jackson and Ward, 1999) where indigenous peoples retained control over contributing variables such as diet.

The causal relationship between the acts and omissions of governments and contemporary indigenous ill health suggests that policy ought to transcend purely clinical responses and assume significance as an instrument of reparative justice. When reparative justice is conceptualized in this way it might seek the 'participatory parity' that Fraser (2003) proposes, and this paper aligns with Daniels' (1981) argument that health is special because it is preliminary to substantive access to the 'good life'.

Public acceptance of indigenous claims, in justice, is also historically contextualized. British settlement in New Zealand, as well as in parts of Canada and the Unites States of America, is distinguished from the Australian context by the negotiation of treaties with the indigenous populations to set its terms and conditions and to secure at least the appearance of moral legitimacy for the colonial project. Although these treaties tended to be one sided and principally a British political strategy to secure authority until such time as they could obtain it by force (Markus, 1994), they have had long-term and unintended moral, jurisprudential and political authority which indigenous peoples have, in modern times, been able to draw upon to claim extant political rights from the state. However, just as treaties have had formative influence over the ways in which some post-colonial jurisdictions understand the rights of indigenous peoples, the absence of an instrument of comparable jurisprudential significance in Australia means that Australians are generally reluctant to accept rights-based notions of indigeneity as either a legitimate or pragmatic framework for policy development. Indeed, it was its rejection of indigenous rights as a legal construct that explained the Howard government's (1996-2007) 'practical reconciliation', which it distinguished from alternative rights-based policy recommendations.

The prevailing rationale was that indigenous people had no further or differentiated rights to political participation than those available to them as Australian 
citizens, and that previous attempts at self-determination had failed to deliver improved policy outcomes (Sanders, 2004). The Rudd government's (2007-2010) apology to the stolen generations (indigenous people forcibly removed from their families by the state from the early 1900s until the early 1970 s to facilitate assimilation into white society) in 2008 did not challenge the prevailing paradigm of indigenous exclusion from the policy process. Nor did the associated 'closing the gap' strategy of raising indigenous life expectancy to that of the non-indigenous population (Pholi et al., 2009), and when self-determination did carry influence, from the mid-1970s to the mid-1990s, it was distinguished by ad hoc measures rather than the fundamental shift in thinking about indigenous citizenship that this paper proposes. The continuing and pervasive influences of these historical and contextual considerations explain the proposition that equitable indigenous access to a culturally responsive policy process is preliminary to sustained improvements in indigenous peoples' health outcomes.

\section{III health and the politics of responsibility}

However, there are important tensions in the politics of indigenous health, which perhaps explain why it is not a policy domain attracting sustained public concern. Relationships between group ill health and propensity to engage in risky behaviours are evident in the higher than expected indigenous 'age cause-specific' death rates, which could be cited to support the libertarian argument that 'society has no obligation of justice (as opposed to charity) to provide the poor with what they are missing' (Daniels et al., 1999: 226). Conversely, while ill health is often the outcome of poor lifestyle choices, it is a misrepresentation of the breadth of its contributing variables to argue that illnesses are only unfortunate, rather than unjust, because nobody else has actually caused them (Engelhardt, 1986). The disproportionate burden that history places on public health resources transcends the unfortunate, and addressing that burden from reparative as well as distributive perspectives acknowledges the original contributing injustices. Framing health policy in reparative terms is an 'an acknowledgement on the part of the transgressor that what he is doing is required of him because of his prior error' (Boxill, 1972: 118). Positioning health policy within a wider politics of reparation gives substantive significance to the formal parliamentary apology in 2008 to the indigenous people who were forcibly removed from their families during the twentieth century, and provides a sense of moral urgency to improving indigenous health outcomes. Apologies contextualize reparation's moral purpose. In line with an increasing number of international examples, the apology to Australia's stolen generations applies a Christian theology of reconciliation to secular political contexts. Both theologically and politically, 'sorrow' is preliminary to just public relationships and the universal exercise of political freedoms. Sorrow, through the reconciliation movement that was politically prominent during the 1990s, has positioned reparative justice at the forefront of indigenous-state relationships and helps to establish who should offer reparation to whom and for what. 
Schmidt (2009) argues that, rather than attempting to apportion personal blame for ill health, solidarity requires attention to its underlying causes. Acts and omissions of governments have compromised indigenous access to the determinants of health, and solidarity should 'guide us in determining questions around access to treatment, and, generally, prompt us to provide it' (Schmidt, 2009: 27). Even if the balance of responsibility rests with the individual, the remaining contributing variables establish grounds for public attention, and show that, while inequalities can sometimes be just, the necessary conditions do not apply in the present context. For example, differences in income, which is a determinant of health, are legitimate if they are 'attached to positions and offices open to all' (Rawls, 1971: 53). Yet, income inequalities can also arise from unjust determinants for which Rawls does not account; for example, relationships between land alienation and economic capacity, and inadequate schooling and access to the primary labour market. The Queensland Wild Rivers Act 2005 is illustrative of further public policy decisions impeding indigenous economic opportunities. Its alleged rationale was to protect the environmental heritage of the Cape York region in northern Queensland. However, its restrictions on indigenous communities' authority to use traditional lands for commercial purposes is relevant to relationships between incomes and good health (Daniels et al., 1999), as well as relationships between health and indigenous opportunities in environmentally focused, physically demanding 'caring for country' projects on traditional indigenous lands (Burgess et al., 2009; Rowley et al., 2008).

Personal responsibility assumes that people have the capability to make informed choices commensurate with good health. Informed choices require capability:

If many people in a cultural group or class behave similarly, there may also be factors at work that reduce how voluntary their behaviour is and how much responsibility we should ascribe to them for it. The analysis thus leaves us with the unresolved complexity of these judgments about responsibility and, as a result, with disagreements about fairness.

Daniels et al. (1999: 25-26)

The ways in which societies ration health resources is a guide to their broader conceptions of justice and how they view the unequal and arbitrary outcomes of the 'natural lottery' (Rawls, 1971: 15). The simplicity and low cost with which many of the contemporary problems in indigenous health can be addressed contextualizes arguments that indigenous claims unfairly burden the public health system as 'conflicts on (rather than of) justice which are the result of ignorance, confusion or other shortcomings' (Boot, 2009: 25). In 2007, the shortfall in primary health expenditure for indigenous people was estimated as being as little as $\$ 460$ million annually (Australian Medical Association, 2007), suggesting that political and administrative barriers to the allocation of public money for indigenous benefit perhaps prevail over fiscal constraints. As the Aboriginal and Torres Strait Island social justice 
commissioner remarked at the time, it is not credible to suggest that one of the wealthiest nations of the world cannot solve a health crisis affecting less than $3 \%$ of its citizens' (Calma, 2007).

Budgetary allocations are ad hoc and compartmentalized in ways that inhibit the integration of clinical with non-clinical determinants of health. Budget items are categorized according to the following clinical priorities: "preventing and managing chronic disease; improving access to maternal and child health services; improving access to effective primary health care and substance use services; improving social and emotional wellbeing services; and improving workforce capacity' (Commonwealth of Australia, 2010). These are essential policy priorities, but they are not the sum of those variables reasonably demanding policy attention. Policy coherence requires complementary and systematic attention to housing, education and labour market policies along with secure rights to the economic development of collective resources as further political determinants of health.

\section{Health, justice and the politics of participation}

Political arrangements influence people's capacity to function as best they can. It is a well-developed principle in political philosophy that the best arrangement is that which is conducive to anyone being able to live a flourishing life (Aristotle, 1998). The pursuit of the 'good life' juxtaposes the politics of indigeneity with Sen's development of Aristotle's thought into a theory of human capability, partly measurable by health outcomes (Sen, 2004: 23). Capability provides a framework for thinking about the fair distribution of resources and the state's role in maximizing personal agency. Just as it has diminished personal agency, public policy has the means to improve individual capacity 'to function well if one so chooses' (Nussbaum, 1987: 20). The capability view helps to mediate conflicting claims by differentiating 'achievement' from the 'freedom to achieve' (Ruger, 2006b: 288).

The idea that public policy ought to focus on personal 'freedom to achieve' recognizes that the 'good life' is both culturally located and relative to political possibilities. In extending a general theory of capability to health, Ruger (2010) argues that, by protecting the conditions that allow people to make lifestyle choices consistent with good health, one establishes the conceptual foundation for 'finding a balance between paternalism and autonomy' (Ruger, 2010: 41). In addition, one diminishes the importance of debates about personal irresponsibility.

Indigeneity proposes that individual liberties are dependent on group rights. It maintains that political participation is reasonably the concern of peoples as well as individuals, with no one culture providing the normative foundation for the conduct of public affairs (O'Sullivan, 2007). Indigeneity is rights-based rather than needs-based politics, transcending distributive concern for what is owed to the most economically disadvantaged. Maaka and Fleras (2005) have argued that, in New Zealand as well as in Canadian contexts, there is a 'sharply etched' distinction between 'needs' and 'rights' as a public policy rationale because 'a needs discourse is concerned with reducing disadvantage by removing discriminatory barriers. 
By contrast, a rights-based discourse focuses on the particular claims to rightful entitlements' (Maaka and Fleras, 2005: 139). There is, first and foremost, a right to belong to the modern state with reference to contemporary self-defined aspirations. For indigenous peoples, these may extend beyond physical and mental well-being to a conception of health concerned with the social, emotional and cultural welfare of the whole community (National Aboriginal Health Strategy Working Party, 1989).

As Durie (2008: 370) argues: 'The principle [of indigeneity also] goes beyond cultural recognition to claim a special place for indigenous peoples in the life of the nation'. Indigenous health policy therefore has implications beyond the simple objective of meeting a 'need' for public services. Instead, if contemporary public policy ought to consider the implications of historic breaches of the rights of indigenous people, it is intellectually, if not politically, a short step towards recognizing the contemporary relevance of a rights discourse to public policy, which raises the question: 'what recourses exist in political theory for thinking about the possibilities of a non-colonial relation between indigenous and non-indigenous peoples?' (Tully, 2000: 50). In other words, how should indigenous people, as a means of democratic participation, be involved in policy-making and what role should culture play in service delivery? A parallel consideration is that:

...we are justified in claiming a right to health care only if it is derivable from an acceptable, general theory of distributive justice... Still, many who assert a right to health care have in mind no particular theoretical account of it.

Daniels (1979: 4)

In Australia, the prevailing general theory of distributive justice is a simplistic one, consistent with Kymlicka's (1995) explanation of a commonly held argument that indigeneity, like ethnicity, is a matter only of private concern. One ought to be free to live according to preferred cultural norms in one's own home, but in the public sphere democratic equality requires institutional homogeneity and public policies indifferent to group identity. There is, perhaps, a fear that the politics of recognition are concerned with granting public privilege to some groups over others. Conversely, for Fraser (2003), group recognition is an essential requirement of justice:

It is unjust that some individuals and groups are denied the status of full partners in social interaction simply as a consequence of institutionalised patterns of cultural value in whose construction they have not equally participated and which disparage their distinctive characteristics.

Fraser (2003: 29).

In other words, in the absence of a treaty or some other form of negotiated British settlement, indigenous people were not involved in setting the terms of colonial engagement. They are now required to seek health and health care through 
institutions whose patterns of operation affect them in disadvantageous ways by continuing to operate exclusively and by according normative privilege to the preferences and practices of other cultural groups.

It is also true that if liberal political theory was developed to determine how societies should admit religious plurality, it ought to be able to rationalize ethnic diversity and the political implications of some citizens' claim that certain rights arise from their membership of an indigenous group. As Kant (1970) has observed:

Men have different views on the empirical end of happiness, and what it consists of, so that as far as happiness is concerned, their will cannot be brought under any common principle, nor thus under an external law harmonizing with the freedom of everyone.

Kant (1970: 73-74).

Rawls proposes a theory of justice as fairness that 'contains principles that give a plausible account of the fair distribution of those determinants' of health (Daniels, 2001: 2). Although Rawls did not place health among his primary goods, Daniels argues that his account of justice is relevant to health care because it protects equal liberties and access to public services and provides a rationale against race- or classbased disadvantages (Daniels, 2001: 2). It is an account of justice that has society's 'basic structure' as its 'primary subject' and that protects minority interests by assuming that each 'person possesses an inviolability ... that even the welfare of society as a whole cannot override' (Rawls, 1971: 3). Its concern for equal liberty is based on the proposition that 'justice denies that the loss of freedom for some is made right by a greater good shared by others' (Rawls, 1971: 3-4). When political arrangements are made with at least some concession to these principles, it becomes more likely that power will be distributed in ways that allow people to participate more equitably in policy decisions. In the present context, these Rawlsian principles are preliminary to the human flourishing that Aristotle explains as the end of political activity (Aristotle, 1988). The capacity to flourish is an essential public policy concern and it is the responsibility of the political order to see that everybody may share in the good life (Aristotle, 1988). The question then becomes one of which political philosophy would most reasonably and substantively extend 'happiness' to the greatest number of indigenous people, given that happiness must at least take into account the determination of indigenous peoples to retain their own distinctive cultural identity, avoid assimilation and exercise a degree of autonomy' (Durie, 2008: 370).

\section{Health, culture and the politics of participation}

Participatory democracy affirms the reasonable expectation that public health policies focus more sharply and unapologetically on indigenous peoples' historically and politically shaped needs and expectations. For example, it is inadequate to propose that an equal per capita distribution of public funding makes health expenditure just. Health policy's fuller purpose is to preserve human dignity and 
maximize opportunity for social participation. Resources are simply a means to an end, bearing no intrinsic value of their own. It is health care's ends that make it morally important (Daniels, 2001: 2) and that establish outcomes as the essential test of a just public policy.

Political participation is usually correlated with wealth (Daniels et al., 1999: 27), which is in turn correlated with good health. The right to political participation is grounded in Aristotle's conception of justice, which makes it reasonable for governments to assume 'responsibility for developing individual capabilities for participation and deliberation' as 'a constitutive part of public policy' (Ruger, 2006b: 292). In reference to Sen (1999), Ruger goes on to explain that participation is both 'instrumental and constitutive' (Ruger, 2006b: 298) of a just policy process. Participation is instrumental because informed and unregimented formation of our values requires openness of communication and arguments ... '(Sen in Ruger, 2006: 298) and constitutive because public debate is 'crucial to the formation of values and priorities' (Sen in Ruger, 2006: 298). For these reasons, one can admit the New Zealand Māori right to elect their own members to parliament is one which particularly enhances deliberative capacity. Guaranteed and, in practice, proportionate indigenous parliamentary representation is a conditional and qualified, yet still substantive, illustration of democratic participation which directly affects New Zealand's indigenous health policy environment. Māori claims are certainly constrained and mediated by a subordinate relationship with the state, but political significance remains attached to the Māori position as peoples whose cultures and occupation of the land pre-date the entrenchment of colonial government.

Contemporary New Zealand politics are distinguished by a developed politics of indigeneity, which confronts the state's assumption of exclusive sovereignty in favour of a political philosophy allowing all citizens to contribute to the development of the national community. New Zealand goes some way towards providing Australia with an alternative framework for thinking about liberal political possibilities, based perhaps on the fundamental questions Benhabib (2004) raises about democratic inclusivity and responsiveness:

Does democracy rest on homogenising models of identity? What does the body of the 'body politic' look like? Can the ideal of universal citizenship accommodate difference? What institutional cultural, representational channels are there for the expression of difference? How much difference is compatible with the ideal of the rule of law under fair and equal conditions?

Benhabib (2004: 5).

In addition, Fraser's (2003) 'participatory parity' is an analytically instructive concept for thinking about just political relationships and the 'independence and voice' that equal political authority and social participation demand. Participatory parity provides ways of assessing the political values informing policy proposals and, in particular, identifying proposals that are likely to be injurious to indigenous peoples' political opportunities. 
New Zealand's relatively better indigenous health is principally explained by policy paradigms more attentive to the role of culture in health care and more willing to countenance specific forms of indigenous participation in policy-making. There is a contested, but still politically established, view that liberal democracy is not affronted by systemic recognition of difference and the cultural precepts and political aspirations of one group of citizens whose democratic expectations are conditioned by colonial experiences.

Colonialism inevitably positions culture as a mark of political distinction. Benhabib (2002: 8) explains that 'struggles for recognition ... are really efforts to negate the status of "otherness" insofar as otherness is taken to entail disrespect, domination and inequality'. However, at the same time, the politics of indigeneity are concerned with recognition to protect the positive characteristics of 'otherness' and ensuring that indigenous people are able to bring these into the policy process. Culture is a determinant of health and the extent to which it reasonably influences public policy is an inescapably political question. The very concept of 'otherness' is itself deeply political because:

Whether in the psyche of the individual or in the imagined community of a nation, it is very difficult to accept the "other" as deeply different while recognizing his/her fundamental human equality and dignity. I argue that the task of democratic equality is to create impartial institutions in the public sphere and civil society where this struggle for the recognition of cultural differences and the contestation for cultural narratives can take place without domination.

Benhabib (2002: 8)

Māori parliamentary representation and ministerial appointments moderate the state's coercive capacity over Māori people because they ensure that policy priorities are set with significant Māori input. Māori parliamentary and ministerial representation also contributes to the Treaty of Waitangi having sufficient status to help conceptualize and contextualize the right to health care in ways that respond to Ruger's concern that giving effect to a human right to health care is compromised by difficulties 'in determining the scope and content of such a right' (Ruger, 2006: 312).

The Treaty of Waitangi is an agreement signed in 1840 between the British Crown and the Chiefs of the United Tribes of New Zealand. It legitimized the establishment of colonial government, while affirming certain Māori cultural, property and participatory rights. A succession of political and jurisprudential developments since the 1970s has confirmed its contemporary significance. It is, for example, noteworthy that in 'order to recognise and respect the principles of the Treaty of Waitangi', the New Zealand Public Health and Disability Act 2000 'provides for mechanisms to enable Māori to contribute to decision-making on, and to participate in, the delivery of, health and disability services' (New Zealand Public Health and Disability Act, 2000, section 4). The act assures Māori representation on district health boards that 
are required to work with Māori communities to establish local priorities and report to parliament on their contributions to improvements in Māori health (New Zealand Public Health and Disability Act, 2000).

Māori are routinely represented on professional registration boards that are required to establish measures of cultural competence as part of their professional certification procedures (Health Practitioners' Competence Assurance Act, 2003). Māori-established primary health organizations are able to contract with district health boards to provide primary services. The assimilationist paradigm evident in indigenous Australian health policy is consequently not as strongly paralleled in Māori health, where Durie (2008) proposes 'pathways' for the realization of Māori health goals, to create space for the exercise of self-determination in health care alongside the proposition that the state ought to take more culturally responsive approaches to health service delivery.

The right to culture is recognized in international law and is an essential claim of the politics of indigeneity. Culture is a determinant of health, and there is a multidimensional case for reducing the cultural dissonance between health providers and indigenous patients. In 2010, the New Zealand government began implementing Whānau Ora (family well-being) as a comprehensive policy measure to integrate the provision of government services to Māori families in ways that are consistent with cultural values and priorities. Whānau Ora is a policy initiative of the Maori Party, a junior partner in the coalition government, which addresses relationships between culture, economic security and political participation as determinants of health and broader well-being. The relationships implicit in the policy goals are that:

- The role of whānau [families] as agents for promoting healthy lifestyles are to be endorsed and supported.

- Full whānau participation in society is to be recognized as a right of citizenship.

- Confident whānau participation in te ao Māori [the Māori world] is to be encouraged as a pathway towards Whānau Ora.

- Economic planning for whānau aim to generate levels of security and wealth that will offer certainty for current and future generations (Taskforce on Whānau Centred Initiatives, 2010: 48).

New Zealand's policy process, which allows the philosophical paradigm implicit in Whānau Ora to command significance, means that it comes much closer than Australia to reflecting the ideal that:

Those who hold different conceptions of justice can, then, still agree that institutions are just when no arbitrary distinctions are made between persons in the assigning of basic rights and duties and when the rules determine a proper balance between competing claims to the advantages of social life.

Rawls (1971: 5) 
This ideal indicates the philosophical breadth required to support the development of a culturally respectful health system involving indigenous people in setting priorities and determining and allocating public budgets, which is justified because 'the capability of persons to determine and justify their own actions, with their ability to determine among alternative political programmes' is the 'core of the modern liberal democratic project' (Held, 1995: 149). Conversely, exclusive political arrangements diminish indigenous opportunities for substantive policy engagement, and the idea that a citizen is one who participates in public deliberation (Aristotle, 1988) is compromised. Participation also provides protection against what Mill (1985) has called:

The tyranny of the prevailing opinion and feeling [and]; against the tendency of society to impose, by other means than civil penalties, its own ideas and practices as rules of conduct on those who dissent from them; to fetter the development, and, if possible, prevent the formation, of any individuality not in harmony with its ways, and compel all characters to fashion themselves upon the model of its own.

Mill (1985: 63)

Equitable political participation does not assure a just distribution of the burden of disease, but it does mitigate against policies that perpetuate disadvantage. Procedural fairness in public decision-making also provides ways of determining the relative justice of conflicting demands on the state. Its association with relational justice responds to a 'violation or denial of just terms of association' (Ivison, 2002: 100), which envisages political relationships of democratic equality that might, for example, extend to the development of a health system recognisant of indigenous knowledge and value systems, and that admits that one's place in the political order contributes to opportunities to live the 'good life'.

Durie proposes a 'link between cultural certainty and good health' (2008: 7) to make the point that health outcomes transcend clinical practices and require a shift in underlying political values about relationships between health and culture. Recognizing the relationship is preliminary to people's ability to conceptualize health in their own terms and for their own reasons. It maximizes systemic capacity to support equitable treatment outcomes and establishes a democratic argument for nationally mandated, culturally safe clinical practices because 'unsafe cultural practice...diminishes, demeans or disempowers the cultural identity and well being of an individual' (Nursing Council of New Zealand, 2002). Unsafe practices diminish people's capacity to take responsibility for their own health and systemic capacity to give all people an equal opportunity to access effective treatment.

Carter et al.'s (2009) analysis of Australian cancer policy papers over the previous 10 years found culture referred to only in deficit terms. Culture was presented as a negative determinant of health because Aboriginality puts one at greater statistical risk of developing the disease. The possibility of locating treatment and care in the cultural context was not considered, yet, in New Zealand, parallel policy statements referred to ethnic disparities not simply to position culture as a risk 
factor but to use 'the cultural values and understandings of Māori...to talk about cancer risk' and to develop strategies for risk reduction (Carter et al., 2009: 1453).

Cultural safety assumes that the prejudices and biases of individual actors and institutions will be removed from the policy process. In 2004, the Australian Health Ministers' Advisory Council adopted a cultural respect framework to recognize relationships between culture and health in ways that could purposefully be incorporated into the 'closing the gap' strategy, adopted by the Council of Australian Governments in 2007 with the complementary aims of increasing indigenous life expectancies to the level of other population groups and halving the indigenous child mortality rate (Council of Australian Governments, 2010). The cultural respect framework proposed that public hospitals ought to recognize relationships between culture and health outcomes by, for example, ensuring that indigenous patients have access to interpreters and traditional healers and that specific indigenous protocols and guidelines be established in maternal health as well as in responding to indigenous deaths (Australian Health Ministers' Advisory Council, 2004: 10-12). Rather than integrating these principles into its own, the distributive focus of 'closing the gap' occurs in isolation from broader culturally defined characteristics of good health. Its focus is not on the full measures of social exclusion (Altman et al., 2008), and the policy functions in the absence of adequate data collection and statistical reporting systems (Australian Institute of Health and Welfare, 2010). 'Closing the gap' is not on its own 'a novel or particularly promising approach', especially as it is guided by assumptions of human deficit, and 'illustrates a substantial imbalance in power and control over the indigenous affairs agenda... which is the "gap" that must be addressed for the health and wellbeing of Indigenous Australians to improve' (Pholi et al., 2009: 1).

However, more importantly from a philosophical perspective, statistical equality alone reduces indigenous aspirations to a 'practical' politics of 'need'. Extant rights to land, language and culture are superseded, and their relationship to good health set aside as 'need' is positioned as the only obligation that citizenship puts upon the state. In this sense, 'practical reconciliation' and its principles, which remain evident in 'closing the gap', can be understood in relation to Taylor's (1999) theoretical articulation of democratic exclusion:

You, like the rest of us, are free by virtue of the fact that we are ruling ourselves in common and are not being ruled by some agency that need take no account of us. Your freedom consists in the fact that you have a guaranteed voice in the sovereign, that you can be heard, and that you have some part in making the decision. You enjoy this freedom by virtue of a law that franchises all of us, and so we enjoy this together. Your freedom is realized and defended by this law, and this whether or not you win or lose in any particular decision. This law defines a community of those whose freedom it realizes and defends together. It defines a collective agency, a people, whose acting together by the law preserves their freedom.

Taylor (1999: 267) 
In contrast, a reparative approach could help to reduce the 'power gap' that Pholi et al. (2009) identify. Substantive reparation is a preliminary condition for considering Waldron's (2002) argument that the principles of universal egalitarian justice are sufficient to protect the needs and rights of all peoples. He proposes that the argument holds regardless of any injustices that may have previously been occasioned by one group over another. The assumption that later events supersede injustice and may even leave the once-aggrieved party better off does not consider that, for indigenous people, injustice is not a single event overridden by some subsequent positive engagements with the post-colonial society. Further, the 'causal connection' between indigenous dispossession and contemporary social, political and economic disadvantage 'is structural or systematic rather than traceable to individual unjust acts' (Patton, 2005: 264). Their minority status, general absence of secure economic bases and, for most indigenous people, isolation from the principal sites of political power add to the political claim for group-specific measures to ensure access to impartial public institutions.

Reparation implies an inclusive re-conceptualization of indigenous citizenship, allowing a society to examine "the boundaries of the "we", to reconceptualise its sense of itself' (Verdeja, 2008: 218). It privileges equal human dignity over charitable obligations to the poor as a public policy foundation and provides grounds to challenge Verdeja's (2008) assumption that a:

Lack of conceptual clarity about what exactly reparations are for - are they meant to return victims to the status quo ante, serve as a moral repudiation of the past, enable once-oppressed groups to achieve self-actualization, or something else? - has meant that reparations programs risk becoming normatively confused and practically ineffective.

Verdeja (2008: 208)

In 2009, the National Health and Hospitals Reform Commission substantively considered ways in which the health sector's administrative structures could promote indigenous self-determination, especially through community health services. The commission proposed that community health services ought to provide services to a single indigenous purchasing authority, with assured indigenous representation. The structure would allow indigenous community-controlled health services to share power and authority as well as provide the administrative simplicity of working with only one government purchasing agent (National Health and Hospitals Reform Commission, 2009). It may simultaneously extend contemporary policy measures and address some significant shortcomings in administrative arrangements. As the independent 'closing the gap' campaign co-chair Tom Calma (2010) put it:

A good start has been made by the government to addressing indigenous health equality but ultimately inequality will only be addressed if all departments and agencies work collectively and cooperatively in partnership with Aboriginal and Torres 
Strait Islander people. That is why we look forward to working with Prime Minister Gillard to Close the Gap (p. 1).

The commission's proposals would 'indigenize' the mainstream policy process in ways likely to counter the influences of prejudice, policy inertia and bureaucratic complexity in policy-making and implementation.

The proposal's concession to indigenous self-determination reflects a significant shift in public policy thinking, which would create limited, but significant, scope for indigenous communities to claim shared political authority with the state. Indigenous involvement as both purchasers and providers of health services would create new political space for indigenous people to frame the policy process in their own ways and for their own purposes. Indigenous engagement in the policy process protects the role of culture, a necessarily public construct, in indigenous peoples' relationships with public institutions. The commission's recommendations have not, as yet, attracted significant policy attention, but any debate that does arise will be a contestation of 'the extent to which Aboriginal people really are permitted to define their own vision of the good life and require other Australians to let them live it' (Clarke, 2006: 122). Therefore, health policy is central to contemporary Australian debates over the claims of indigeneity and its limits. It is also central to the re-construction of citizenship and the distribution of political authority to accept indigenous expectations of reparation, respect and autonomy.

\section{Conclusion}

The description of those non-clinical variables that contribute to relative indigenous Australian ill health as social determinants can understate their inherently political character. Inequities in housing, education, labour market participation and access to economic assets reflect deeply political characteristics of the complex social system. Considered political decisions in these areas, as well as in health itself, reflect the distribution of public authority, and make judgements about the purpose of political activity and the justice of collective indigenous participation in the policy process. Political and administrative decisions also influence the cultural responsiveness of public institutions and create space for political values about relationships between health and culture to influence policy outcomes.

The ways in which societies share public authority is an indication of their conceptions of justice and willingness to function as inclusive political communities. Yet, there is recourse within liberal political theory, juxtaposed with the politics of indigeneity, for securing the substantive democratic engagement of indigenous people, including participation at every stage of the health policy process. Australia can draw policy lessons from New Zealand on the indigenization and representative participation of indigenous peoples in policy-making, as well as in the recognition of relationships between health and culture. In these ways, one can complement distributive arguments for particular attention to indigenous health with reparative positions responsive to the relationships between colonial 
history and health. At the same time, contemporary political exclusivity is challenged by arguments for 'participatory parity' as a matter of democratic legitimacy and moral urgency to admit that group recognition is preliminary to just political outcomes. It is only on account of their indigeneity that individual members of the group have been affected by colonialism's necessarily exploitative logic. Injustice has occurred in specific contexts peculiar to the group, which means that general appeals to principles of egalitarian justice will be insufficient to protect indigenous people's individual liberties and opportunities to share in the 'good life'. Culture, first occupancy and claims that reparative principles ought to inform policy development add to the political nature of the determinants of indigenous health and are reasonably integrated into policy frameworks concerned with indigenous peoples' health and well-being.

\section{Funding}

This research received no specific grant from any funding agency in the public, commercial, or not-for-profit sectors.

\section{Declaration of Conflicting Interests}

The author declares that he does not have any conflicts of interest.

\section{References}

Altman JC, Biddle N, Hunter B (2008) How Realistic Are the Prospects For 'Closing the Gaps' in Socioeconomic Outcomes for Indigenous Australians? Canberra: ANU Centre for Aboriginal Economic Policy Research.

Australian Health Ministers' Advisory Council (2004) Cultural Respect Framework for Aboriginal and Torres Strait Islander Health. Available at: http://www.sa.gov.au/ upload/franchise/Seniors/Cultural\%20Respect\%20Framework.pdf (accessed on 25 January 2010).

Australian Institute of Health and Welfare (2010) Indigenous identification in hospital separations data: quality report. Available at: http://www.aihw.gov.au/publications/hse/85/ 10637.pdf.

Australian Medical Association (2007) Australian Medical Association Report Card Series 2007 Aboriginal and Torres Strait Islander Health: Institutionalised Inequity Not Just a Matter of Money. Canberra: Australian Medical Association.

Aristotle (1988) The Politics. Cambridge: Cambridge University Press.

Auditor-General for the Northern Territory (2010) Strategic indigenous housing and infrastructure programme report to the legislative assembly. Australia: Auditor-General of the Northern Territory.

Australian Bureau of Statistics (2009) Deaths Australia, 2008. Canberra: Australian Bureau of Statistics.

Australian Human Rights and Equal Opportunities Commission (2007) Bringing them home: Report of the national inquiry into the separation of Aboriginal and Torres Strait Islander children from their families. Available at: http://www.hreoc.gov.au/pdf/ social_justice/bringing_them_home_report.pdf (accessed on 12 December 2011). 
Benhabib S (2002) The democratic movement and the problem of difference. In: Benhabib S (ed.) The Claims of Culture: Equality and Diversity in the Global Era. Princeton: Princeton University.

Boxill B (1972) Morality of reparation. Social Theory and Practice 2: 113-120.

Boot M (2009) Conflicts of justice. Available at: http://ptw.uchicago.edu/Boot08.pd (accessed on 12 December 2011).

Burgess CP, Johnston F, Berry HL, et al. (2009) Healthy country healthy people: the relationship between indigenous health status and "caring for country". Medical Journal of Australia 190(10): 567-572.

Calma T (2007) Close the Gap: Indigenous Health Campaign. Canberra: Australian Human Rights Commission.

Calma T (2010) Close the Gap-Make it Happen. Media Release. Canberra: Australian Human Rights Commission, 28 June 2010.

Carter SM, Hooker LC and Davey HM (2009) Writing social determinants into and out of cancer control: an assessment of policy practice. Social Science \& Medicine 68(8): $1448-1455$.

Clarke J (2006) Desegregating the indigenous rights agenda. Australian Journal of Legal Philosophy 31: 119-126.

Commonwealth of Australia (2010) Portfolio Budget Statements 2010-2011, Budget Related Paper No. 1.11, Health and Ageing Portfolio. Canberra: Commonwealth of Australia.

Council of Australian Governments (2010) National Indigenous Reform Agreement (Closing the Gap). Available at: http://www.coag.gov.au/coag_meeting_outcomes/ 2009-07-02/docs/NIRA_closing_the_gap.pdf (accessed on 12 December 2011).

Daniels N (1979) Rights to health care and distributive justice: programmatic worries. Journal of Medicine \& Philosophy 4(2): 174.

Daniels N (1981) Healthcare needs and distributive justice. Philosophy and Public Affairs 10(2): 146-179.

Daniels N (2001) Justice, health, and healthcare. American Journal of Bioethics 1(2): 2-16.

Daniels N, Kennedy BP and Kawachi I (1999) Why justice is good for our health: the social determinants of health inequalities. Daedalus 128(4): 215-251.

Durie M (2008) The Wunderly Oration 2007: indigenous responses to health and disease: principles goals and pathways. Internal Medicine Journal 38: 368-373.

Engelhardt HT (1986) The Foundations of Bioethics. Oxford: Oxford University Press.

Fraser N (2003) Redistribution or Recognition?: A Political-philosophical Exchange. New York: Verso Books.

Health Practitioners Competence Assurance Act (2003). Available at: http://www.legislation.govt.nz (accessed on 25 January 2010).

Held D (1995) Democracy and the Global Order: From the Modern State to Cosmopolitan Governance. Cambridge: Polity Press.

Ivison D (2002) Postcolonial Liberalism. Cambridge: Cambridge University Press.

Jackson R and Ward J (1999) Aboriginal health: why is reconciliation necessary? Medical Journal of Australia 170: 437-440.

Kant I (1970) Kant's Political Writings. Cambridge: Cambridge University Press.

Kymlicka W (1995) Multicultural Citizenship. Oxford: Oxford University Press.

Maaka R and Fleras A (2005) The Politics of Indigeneity: Challenging the State in Canada and Aotearoa New Zealand. Dunedin: University of Otago Press. 
Markus A (1994) Australian Race Relations, 1788-1993. St Leonards New South Wales: Allen and Unwin.

Mill JS (1985) On Liberty. London: Harmondsworth: Penguin Classics.

National Aboriginal Health Strategy Working Party (1989) A National Aboriginal Health Strategy. Canberra: Department of Aboriginal Affairs.

New Zealand Public Health and Disability Act (2000) Available at: http://www.legislation.govt.nz (accessed on 25 January 2010).

National Health and Hospitals Reform Commission (2009) A healthier future for all Australians - final report. Available at: http://www.health.gov.au/internet/nhhrc/publishing.nsf/Content/1AFDEAF1FB76A1D8CA257600000B5BE2/\$File/Final_Report_ of_the\%20nhhrc_June_2009.pdf (accessed on 25 January 2010).

Nursing Council of New Zealand (2002) Cultural safety, the Treaty of Waitangi, and Maori health in nursing and midwifery education and practice. Available at: http:// www.nursingcouncil.org.nz/culturalsafety.pdf (accessed on 25 January 2010).

Nussbaum M (1987) Nature, Function, and Capability: Aristotle on Political Distribution. World Institute for Development Economics Research of the United Nations University, Helsinki.

O'Sullivan D (2007) Beyond Biculturalism. Wellington: Huia Publishers.

Oxfam Australia (2007) Close the Gap: Solutions to the Indigenous Health Crisis Facing Australia. Fitzroy: Oxfam Australia.

Patton P (2005) Historic injustice and the possibility of supersession. Journal of Intercultural Studies 26(3): 255-266.

Pholi K, Black D and Richards C (2009) Is "close the gap" a useful approach to improving the health and wellbeing of indigenous Australians? Australian Review of Public Affairs 9(2): 1-13.

Rawls J (1971) A Theory of Justice. Cambridge: Harvard University Press.

Rege S (2009) State of indigenous mental health in Australia - a colonial legacy? International Psychiatry 6(4): 98-100.

Rowley KG, O'Dea K, Anderson I, et al. (2008) Lower than expected morbidity and mortality for an Australian Aboriginal population: 10-year follow-up in a decentralised community. Medical Journal of Australia 188(5): 283-286.

Ruger J (2006a) Ethics and governance of global health inequalities. British Medical Journal 60(11): 998.

Ruger J (2006b) Toward a theory of a right to health: capability and incompletely theorized agreements. Yale Journal of Law \& the Humanities 18: 273-326.

Ruger J (2010) Health Capability: conceptualization and operationalization. American Journal of Public Health 100(1): 41-49.

Sanders W (2004) Towards an Indigenous Order of Australian Government: Rethinking Self-Determination as Indigenous Affairs Policy. Canberra: Australian National University.

Schmidt H (2009) Just health responsibility. Journal of Medical Ethics 35(1): 21-26.

Sen A (1999) Development as Freedom. Oxford: Oxford University Press.

Sen A (2004) Why health equity. In: Anand S, Peter F, Sen A (eds) Public Health Ethics and Equity. New York: Oxford University Press, 21-33.

Smith MS (2004) Review of Benhabib Seyla. The claims of culture: equality and diversity in the global era. Ethics 114(2): 337-340. 
Taskforce on Whānau Centred Initiatives (2010) Report of the taskforce on Whānau centred initiatives. Available at: http://www.msd.govt.nz/about-msd-and-our-work/work-programmes/initiatives/whanau-ora/index.html (accessed on 25 January 2010).

Taylor C (1999) Democratic exclusion (and its remedies?). In: Cairns A, Courtney J, Mackinnon P, Michelmann H, Smith D (eds) Citizenship Diversity and Pluralism: Canadian and Comparative Perspectives. Montreal and Kingston: McGillQueen's University Press.

The Wild Rivers Act (2005) (Qld). Available at: http://www.austlii.edu.au/ (accessed on 25 January 2010).

Tully J (2000) The struggles of indigenous peoples for and of freedom. In: Ivison D, Patton P, Sanders W (eds) Political Theory and the Rights of Indigenous Peoples. Cambridge: Cambridge University Press, 36-59.

Verdeja E (2008) A critical theory of reparative justice. Constellations: An International Journal of Critical and Democratic Theory 15(2): 208-222.

Waldron J (2002) Indigeneity? First peoples and last occupancy. Available at: http:// www2.law.columbia.edu/faculty_franke/Thursday\%20Lunch/Waldron.facultylunch. indigeneity.pdf. 